\title{
OCCUPATIONAL RISKS AND THEIR RELATIONSHIP WITH WASTE DUMPED IN A STREAM OF MANAUSIAM: A QUALITATIVE STUDY OF WORK SAFETY ENGINEERING
}

\author{
Everaldo de Queiroz Limaa ${ }^{\text {, Alexandra de Lima Pereira }}{ }^{a}$ \\ a Occupational Safety Engineering, UNYLEYA - IEMAC, Brazil.
}

\begin{abstract}
Urban waste is a broad problem for society and directly affects the environment, which we can define as the set of conditions that allow sheltering and governing life in all its forms. In this context, a study was carried out to relate occupational risks to the waste dumped in a stream in Manaus, in the area located in the Mindú Municipal Park. The risks were identified and classified through field (in loco) and bibliographic surveys. In a qualitative way, the relationship between occupational diseases and the researched environment was verified and concepts for mitigation were proposed, such as studies on Occupational Safety Engineering, for identification, anticipation of risks and proposing safety and prevention measures for life and health.
\end{abstract}

Keywords: environment; occupational risks; safety at work.

\section{RISCOS OCUPACIONAIS E SUA RELAÇÃO COM LIXOS DESPEJADOS EM UM IGARAPÉ DE MANAUSIAM: UM ESTUDO QUALITATIVO DE ENGENHARIA DE SEGURANÇA DO TRABALHO}

Resumo: Os resíduos urbanos constituem uma problemática ampla da sociedade e afetam diretamente o meio ambiente, este que podemos definir como o conjunto de condições que permitem abrigar e reger a vida em todas as suas formas. Nesse contexto foi realizado um estudo para relacionar os riscos ocupacionais aos resíduos despejados em um igarapé de Manaus, na área localizada no Parque Municipal do Mindú. Os riscos foram identificados e classificados através de levantamento de campo (in loco) e bibliográfico. De forma qualitativa foi verificado a relação das doenças ocupacionais com o meio ambiente pesquisado e proposto conceitos para mitigação como estudos de Engenharia de Segurança do Trabalho, para identificação, antecipação aos riscos e propor medidas de segurança e prevenção da vida e saúde.

Palavras-chave: meio ambiente; riscos ocupacionais; segurança no trabalho. 


\section{INTRODUCTION}

The healthy environment is of fundamental importance for a better quality of life for people within cities, therefore it is necessary to carry out integrated management of urban waste in the management of municipalities, since the inadequate conditioning of waste leads to environmental damage and social, the most serious ones being related to health [1].

Urban waste is a broad problem in society, with a worldwide scope. Since the way garbage is managed can cause damage to both society and nature, its first impacts being identified in the landscape to which they are placed, causing problems from the odor to the focus of diseases. Due to the precariousness of urban infrastructure linked to public cleaning in cities in the last decades, since they do not have urban infrastructure and equipment to accommodate such demand for waste, the problem of garbage comes up, where along with the culture of consumption, it tends increase in the production of waste, which implies the need for actions to carry out its environmentally correct management [2].

When referring to communicable diseases, they have a relationship with the social and economic conditions of individuals and populations, therefore, a sensitive indicator of their health and life levels. Thus, conducting studies on the epidemiology of infectious and parasitic diseases, addressing their distribution in intra-urban spaces can point out important subsidies for the guidance of state interventions, given the capacity that this group of causes has to highlight priority areas [3].

\subsection{Urban waste}

Garbage is designated as all useless, disposable material that is thrown away. It can be composed of: organic material (leftover food), which represents about $65 \%$ to $70 \%$ produced in developing countries; waste (bathroom waste, batteries, lamps), which correspond to $5 \%$ of the total mass of waste, that is, the waste itself that is not amenable to recycling, reuse or composting; and recyclable materials (plastics, paper, metals and glass), which make up approximately $25 \%$ to $30 \%$ of the weight, but which represents the largest portion in volume [4].

The impacts caused by municipal solid waste can extend to the general population, through the pollution and contamination of water bodies and groundwater, directly or indirectly, depending on the use of water and the absorption of toxic or contaminated material. The general population is still exposed to the consumption of meat from animals raised in the dumps and that can cause the transmission of diseases to humans. It is estimated that more than 5 million people die each year, worldwide, due to waste related diseases [1].

\subsection{Diseases caused by garbage dumped in streams}

Diseases sensitive to garbage are caused by viruses, bacteria, worms and parasites, which are present in the decomposing organic matter resulting from the waste and, consequently, from the water in the streams that are infected by the waste decomposition process. The lack of basic sanitation that in the city of Manaus contributes to such pollution, because in addition to waste that is erroneously disposed of in the streams, there is also the release of waste from domestic sewage that does not have treatment due to [5]. 
In general, these waters do not receive any treatment, being open drains, due to the pollution of the waters of the streams, such families are vulnerable to diseases, since the presence of heavy metals due to pollution in the water of these streams is significant. Families living in these areas face multiple problems, such as the spread of water-borne diseases, the flood and ebb cycle that exposes garbage, the stench, among others. The city's urban streams are polluted, taken up by residues and waste in their course, with the decomposition of organic matter present in the garbage, the characteristics of the environment change, becoming a public health problem since the environment will be conducive to the transmission of disease [5,2].

Infectious diseases such as dengue, malaria, diarrhea, leptospirosis and others transmitted by vectors are the main diseases identified in the city of Manaus, which are related to the health of the environment. Hospitalizations due to diarrhea are 1 for every 1,000 inhabitants in the city of Manaus [6].

\subsection{Occupational Risks}

Risks in the workplace can be classified into five types, according to Ordinance no. 3,214, of the Ministry of Labor of Brazil (MTB), of 1978. This Ordinance contains a series of regulatory norms that consolidate labor legislation, related to occupational safety and medicine. To facilitate the prevention of accidents and mitigation of occupational risks, MTB defines a classification by color, designed to facilitate the elaboration of the so-called pope of occupational risks [7]. This important classification is highlighted in table 01.

Table 1: Classification of Occupational Risks [7]

\begin{tabular}{|c|c|}
\hline $\begin{array}{c}\text { GROUP I } \\
\text { Green } \\
\text { Phisical Risks }\end{array}$ & $\begin{array}{l}\text { Noises, vibrations, ionizing radiation, non-ionizing radiation, cold, heat, abnormal } \\
\text { pressures and humidity. }\end{array}$ \\
\hline $\begin{array}{c}\text { GROUP II } \\
\text { Red } \\
\text { Chemical Risks }\end{array}$ & $\begin{array}{l}\text { Dusts, fumes, mists, gases, vapors, substances and compounds or chemicals in } \\
\text { general. }\end{array}$ \\
\hline $\begin{array}{c}\text { GROUP III } \\
\text { Brown } \\
\text { Biological Risks }\end{array}$ & viruses, bacteria, protozoa, fungi, parasites and bacilli. \\
\hline $\begin{array}{l}\text { GROUP IV } \\
\text { Yellow } \\
\text { Ergonomic Risks }\end{array}$ & $\begin{array}{l}\text { Intense physical effort, manual weight lifting and transport, inadequate posture } \\
\text { requirement, strict productivity control, imposition of excessive rhythms, work in day } \\
\text { and night shifts, prolonged work hours, monotony, repetition and other situations } \\
\text { that cause physical stress and/or psychic. }\end{array}$ \\
\hline $\begin{array}{c}\text { GROUP V } \\
\text { Blue } \\
\text { Accident Risks }\end{array}$ & $\begin{array}{l}\text { Inadequate physical arrangement, unprotected machinery and equipment, } \\
\text { inadequate or defective tools, inadequate lighting, electricity, fire and explosion } \\
\text { probability, improper storage, venomous animals and other risk situations that may } \\
\text { contribute to the occurrence of accidents. }\end{array}$ \\
\hline
\end{tabular}

\section{METHODOLOGY}

The study area refers to Stream of the Mindú, located in an urban area of the city of Manaus. It belongs to the São Raimundo hydrographic sub-basin, which is approximately $160.5 \mathrm{~km}^{2}$, has a slope and intense urban occupation [8]. The specific 
place of study was the igarapé area that cuts through Mindú Municipal Park, in the Park 10 de November neighborhood, as shown in figure 02.

Figure 1. Study area within the Mindú Municipal Park [9]

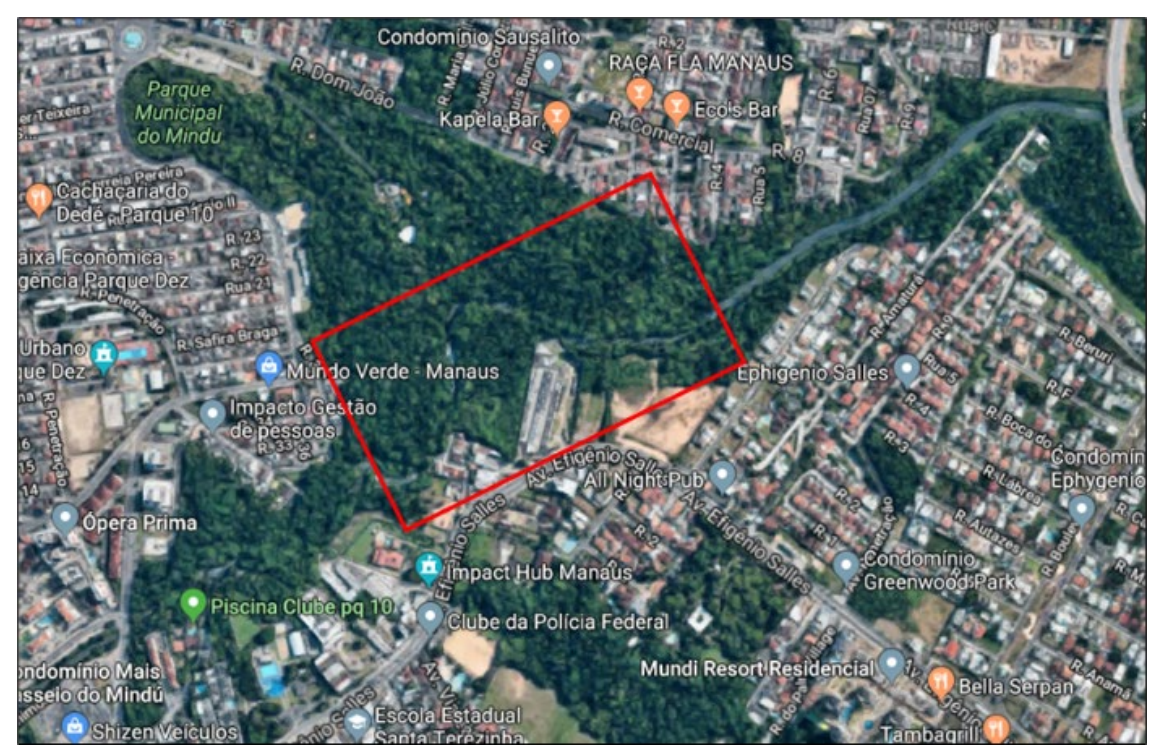

An on-site visit was made to the Mindú Municipal Park and through the existing trails, it was possible to access the Igarapé margin. Photographic images captured by cell phone were taken along the route in which the various wastes and evidence of effluent were directly discharged into the stream bed. Three points were defined to capture the images: Point A: Stream bed; Point B: Margin of stream; Point C: Source at the margin of the stream.

Based on on-the-spot checks and field photographs, a bibliographic survey was carried out in the area of Occupational Health and Hygiene, in order to identify and classify the evident risks in the place selected for study.

\section{RESULTS AND DISCUSSION}

Based on the images captured by cell phone, it was possible to qualitatively identify some risks that directly affect the public health of visitors to the park and workers exposed to these risks.

In figure 2, the bed of the stream is shown, at a point where the water is very agitated (current), which is covered by white foam, the result of domestic and / or industrial effluents that reach the course of the stream. This white foam is formed from chemicals used in detergents, soaps, shampoos, and other cleaning products that react with moving water to form this unwanted aspect in the stream water.

In figure 3 , it shows an image still in point $A$, where the water does not have agitation and the formation of foam is not observed, as in figure 2, however, the cloudy aspect and the unpleasant odor indicate the existence of chemical products in suspension and effluent from domestic sewage that is discharged directly into the stream.

In figure 4, the margin of the stream is shown, which is covered with solid residues that are mostly composed of various plastics, glass bottles, electronics and construction waste (wood logs). 
In figure 5, a spring is shown at the margin of the stream that due to the excess of solid waste in its course, it has a watertight point, which favors the growth of insects such as Aedes aegypti, which transmits dengue and other diseases.

Figure 2. Point A1 - Stream bed

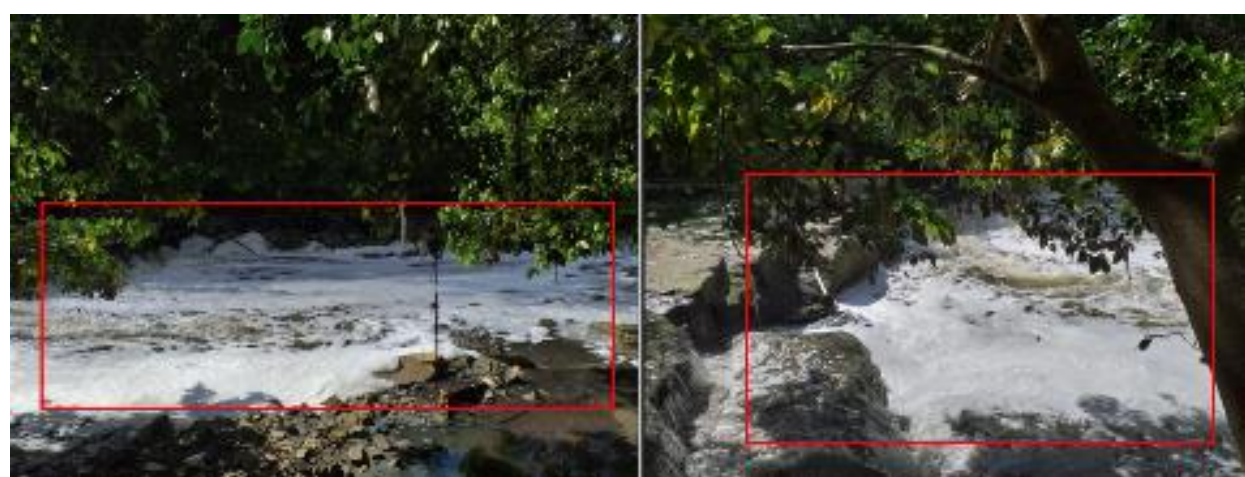

Figure 3. Point A2 - Stream bed

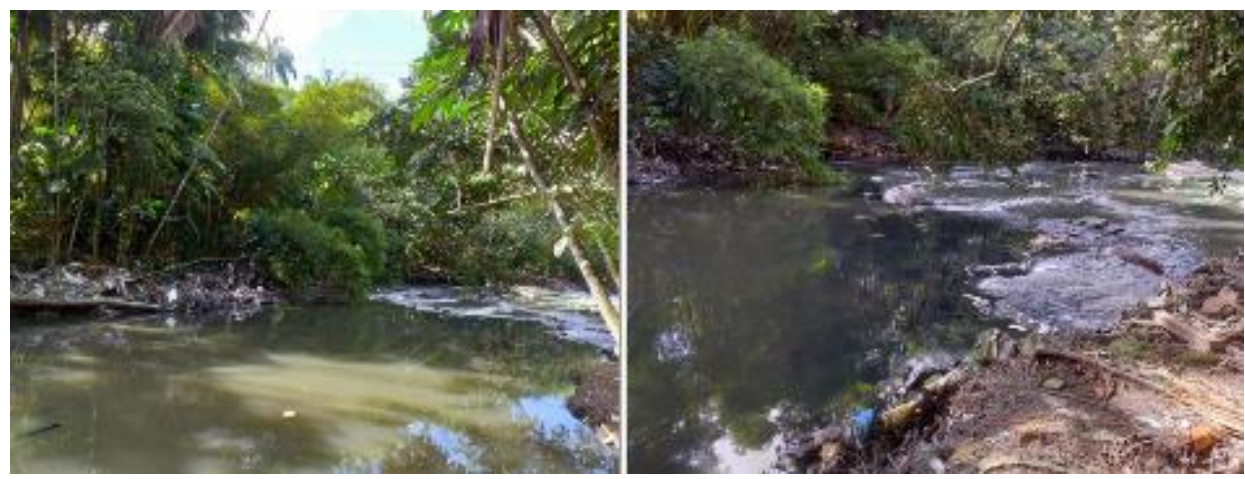

Figure 4. Point B - Margin of stream

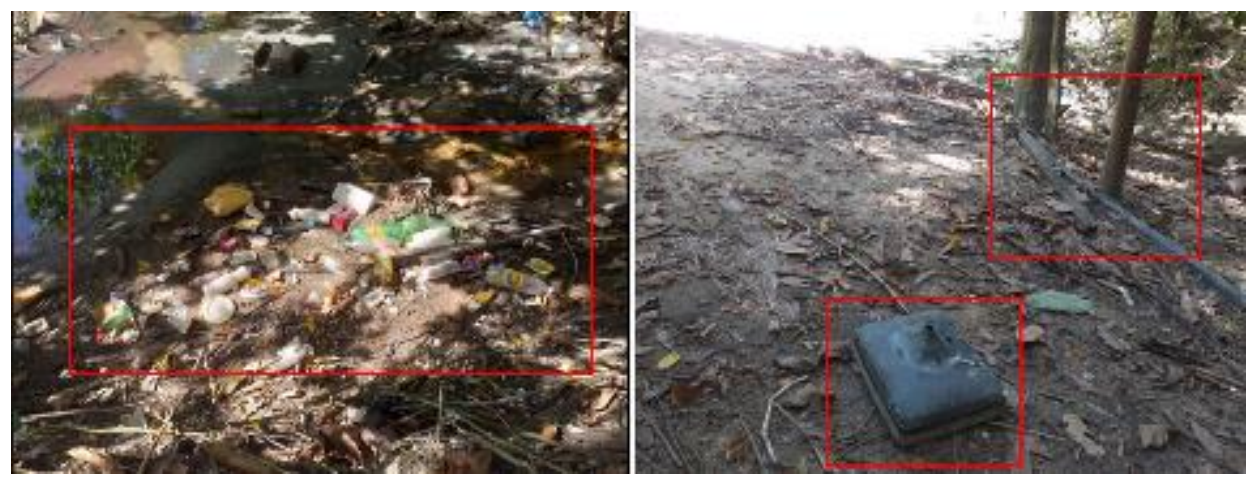

Figure 5. Point C - Spring on the banks of the stream

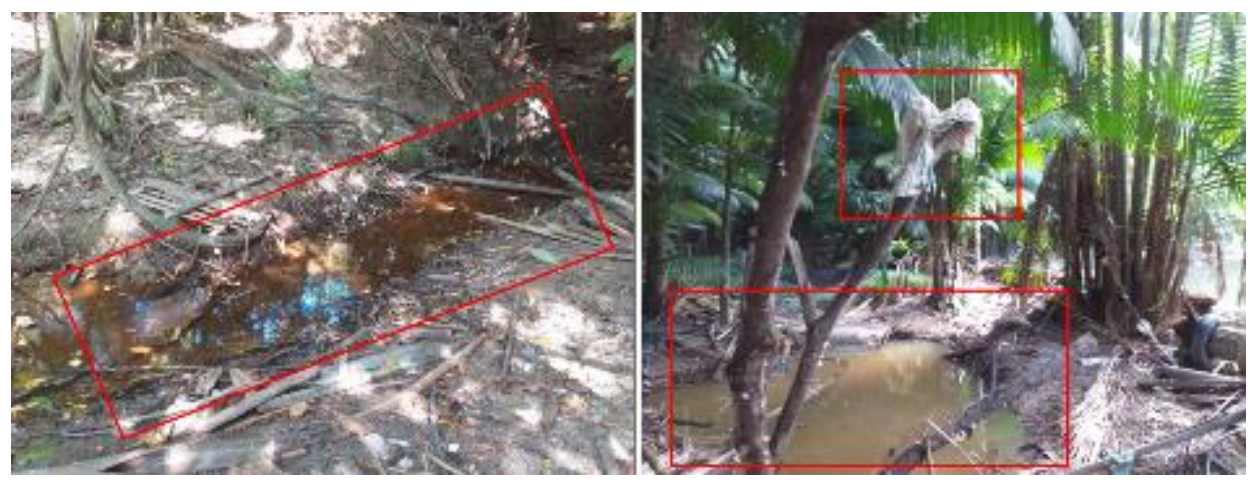


These places have characteristic smells of human waste, evidencing that domestic sewage is discharged directly into the stream, which promotes the growth of bacteria and biological agents that affect human health once it comes into contact.

Occupational risks are the risks that workers are subject to in a work environment, that is, any situation that presents a risk of damage to the worker's health characterizes an occupational risk. Risks in the work environment can be classified into five types according to ordinance n. 3.214 of 1978 from the Ministry of Labor. In the images, several agents were found to offer risks to the health of the worker and thus classify Physical, Chemical and Biological risks as shown in table 2.

Table 2. Classification of risks raised in Stream of the Mindú

\begin{tabular}{|c|c|c|c|}
\hline \multirow{2}{*}{$\begin{array}{l}\text { Study } \\
\text { points }\end{array}$} & \multicolumn{3}{|c|}{ Risk Classification } \\
\hline & Physical & Chemical & Biological \\
\hline $\begin{array}{c}\text { Point A } \\
\text { Stream bed }\end{array}$ & $\begin{array}{l}\text { 1. Humidity and heat } \\
\text { characteristic of the region. }\end{array}$ & $\begin{array}{l}\text { 1. Bad smell - caused by } \\
\text { human waste and waste. } \\
\text { 2. Water turbidity - caused by } \\
\text { detergent chemicals. } \\
\text { 3. Foam - caused by the most } \\
\text { diverse products for domestic } \\
\text { and industrial use in cleaning } \\
\text { processes in general. }\end{array}$ & $\begin{array}{l}\text { 1. Bad smell - caused by } \\
\text { human waste. } \\
\text { 2. Bacteria and fungi - } \\
\text { disseminated by human } \\
\text { waste, decomposing animals, } \\
\text { sewage discharged directly } \\
\text { into streams. } \\
\text { 3. Several vectors that } \\
\text { transmit diseases such as: } \\
\text { flies, mosquitoes, } \\
\text { cockroaches, rats, among } \\
\text { others. }\end{array}$ \\
\hline $\begin{array}{l}\text { Point B } \\
\text { Margin of } \\
\text { stream }\end{array}$ & $\begin{array}{l}\text { 1. Humidity and heat } \\
\text { characteristic of the region. } \\
\text { 2. Fall and Trip - caused by } \\
\text { the excess of solid waste on } \\
\text { the banks of the stream, such } \\
\text { as: pet bottles, tires, couch, } \\
\text { among others. } \\
\text { 3. Cuts and/or perforations: } \\
\text { caused by electrical and } \\
\text { electronic waste, cathode } \\
\text { television tubes, wood with } \\
\text { nails, various waste from civil } \\
\text { construction, among others. }\end{array}$ & $\begin{array}{l}\text { 1. Bad smell - caused by } \\
\text { sewage and human waste. }\end{array}$ & $\begin{array}{l}\text { 1. Bad smell - caused by } \\
\text { human waste. } \\
\text { 2. Several vectors that } \\
\text { transmit diseases such as: } \\
\text { flies, mosquitoes, } \\
\text { cockroaches, rats, among } \\
\text { others. }\end{array}$ \\
\hline $\begin{array}{l}\text { Point C } \\
\text { Source on } \\
\text { the banks of } \\
\text { the stream }\end{array}$ & $\begin{array}{l}\text { 1. Humidity and heat } \\
\text { characteristic of the region. }\end{array}$ & $\begin{array}{l}\text { 1. Bad smell - caused by } \\
\text { human waste and waste. } \\
\text { 2. Water turbidity - caused by } \\
\text { detergent chemicals. }\end{array}$ & $\begin{array}{l}\text { 1. Bad smell - caused by } \\
\text { human waste. } \\
\text { 2. Bacteria and fungi - } \\
\text { disseminated by human } \\
\text { waste, decomposing animals, } \\
\text { sewage discharged directly } \\
\text { into streams. } \\
\text { 3. Several vectors that } \\
\text { transmit diseases such as: } \\
\text { flies, mosquitoes, } \\
\text { cockroaches, rats, among } \\
\text { others. }\end{array}$ \\
\hline
\end{tabular}


Having defined the classification of risks and their agents in table 2, it was possible in a qualitative way to elaborate a risk map of the Stream of the Mindú, in figure 6 , specifically in the place defined with the case study area.

Figure 6. Risk map of the stream in the study area

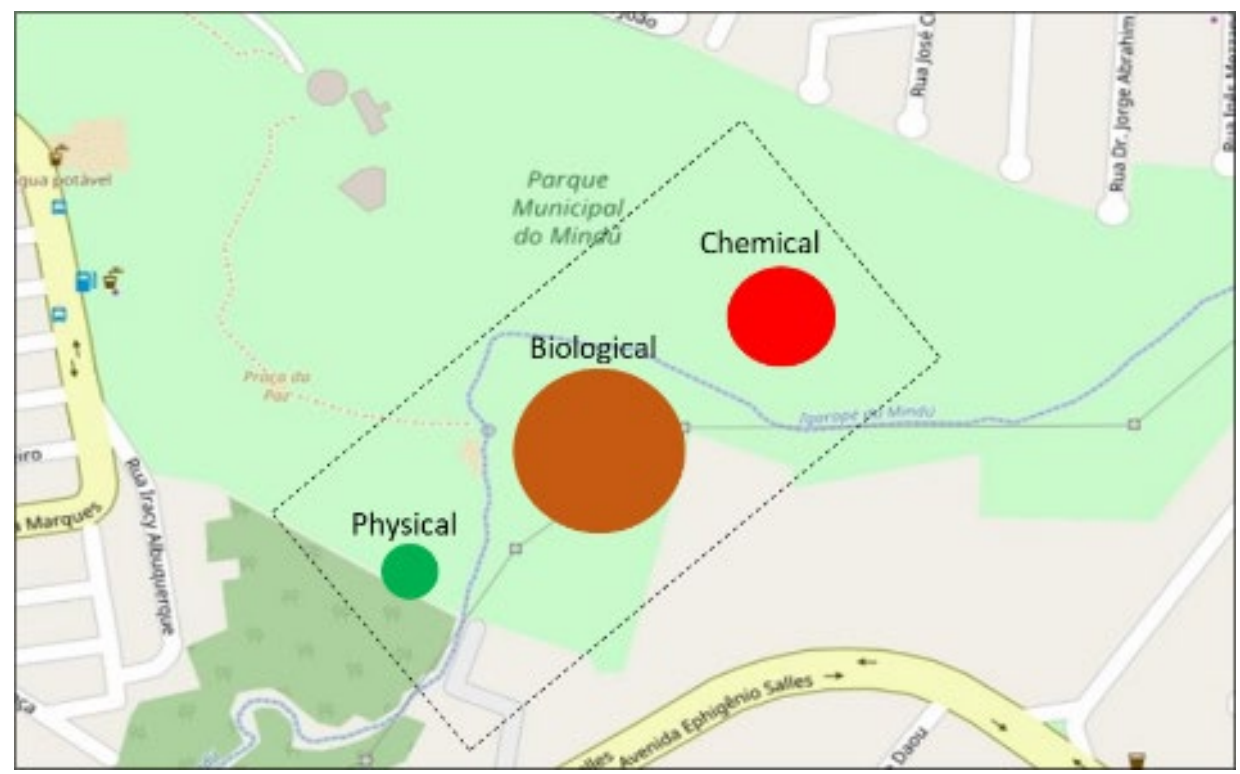

\section{CONCLUSION}

Based on this study, it was possible to relate occupational risks to the waste dumped in the Mindú Stream, specifically in the Mindú Municipal Park, which was the area defined as the study point. Physical, chemical and biological agents were identified and classified based on field and bibliographic surveys. The residues can affect the health of the worker who at some point may have contact with one of these agents.

In greater emphasis are the biological risks arising from human waste, dead animals, domestic and / or industrial sewage discharged directly into the stream, which can cause various infectious or contagious diseases and provide a favorable environment for the proliferation of various vectors that cause and transmit diseases.

Occupational diseases are directly linked with the researched environment, the worker / visitor of the park is exposed to these risks and means of mitigation such as studies of Environment Management and Safety Engineering are essential as a way to identify, anticipate and propose safety measures and prevention of life, health and safety of workers.

\section{Acknowledgments}

To IEMAC and Faculdade UNYLEYA for offering the course, structure and management, and to all professors who contributed in the course of the PostGraduation with the technical, theoretical knowledge and experience in the field of Occupational Safety Engineering. 


\section{REFERENCES}

1 DAMBROS, I. V.; CRUZ, S. F. O. Gestão dos resíduos sólidos. KMC Ed., vol 1, Seminários Regionais Ambientais, Cuiabá, 2012.

${ }^{2}$ COSTA, R. C. Áreas de risco: processos da natureza e produção da sociedade. Revista Geonorte, vol. 4, Ed. Especial, 2012.

3 STOCKWELL, W.R. F.; KIRCHNER, M.; KUHN, S.; SEEFELD, J. Geophys. Res. 102, 1997.

4 GONÇALVES, R. C. M. A voz dos catadores de lixo em sua luta pela sobrevivência. Dissertação, Políticas Públicas e Sociedade, UFSC, Florianópolis, 2005.

${ }^{5}$ PEREIRA, A. U. Impactos dos Resíduos Sólidos Urbanos de Manaus. Trabalho, Gestão Ambiental, UEA, Manaus, 2016.

6 IBGE - Instituto Brasileiro de Geografia e Estatística. Censo séries históricas1970 $-2010$.

7 BRASIL. Portaria n. 3.214 de 08 de junho de 1978 NR-05. Comissão Interna de Prevenção de Acidentes. In: SEGURANÇA E MEDICINA DO TRABALHO. 29 ed. Atlas, São Paulo, 1995.

${ }^{8}$ MACHADO, C.; PRATA FILHO, D. A. Gestão de Resíduos Sólidos Urbanos em Niterói. In: $20^{\circ}$ Congresso Brasileiro de Engenharia Sanitária e Ambiental, Anais. Rio de Janeiro, 1999.

9 GOOGLE MAPS. Imagem do Parque Municipal do Mindú. Disponível em: $<$ https://www.google.com.br/maps/place/Parque+Municipal+do+Mindu>. Acesso em: 07/02/2020.

\section{OTHER INFORMATION}

a) Manuscripts and information included therein are the responsibility of the authors and may not represent the opinion of VI SIINTEC.

b) The authors accept that VI SIINTEC has full rights to the submitted manuscripts and may include them in the proceedings, print them and disclose them, without payment of any kind.

c) Manuscripts will be evaluated by reviewers invited by the Scientific Committee of the Event. Only accepted manuscripts can be presented and published at the event.

For additional clarifications, contact:

Organizing Committee of the Event - siintec@fieb.org.br

SENAI CIMATEC 